Raudhah, Vol. 07 (02), Juli-Desember 2019, ISSN: 2338-2163, hlm. 49-63

JURNAL RAUDHAH

Progam Studi Pendidikan Islam Anak Usia Dini (PIAUD) UIN Sumatera Utara

http://jurnaltarbiyah.uinsu.ac.id/index.php/raudhah

\title{
PENGARUH PENGGUNAAN MEDIA POP UP BOOK TERHADAP KECERDASAN LINGUISTIK ANAK USIA 5-6 TAHUN DI RA NURHAYATI KECAMATAN MEDAN TEMBUNG
}

\author{
Oleh \\ Desi Maisura Sidabutar ${ }^{*}$, Khadijah $^{* *}$, Rohani $^{* * *}$ \\ *mahasiswa PIAUD, **dosen FITK UINSU Medan, *** dosen FITK UINSU Medan
}

\begin{abstract}
Abstrak:
Penelitian ini dilaksanakan di RA Nurhayati Kecamatan Medan Tembung, pada tanggal 25 Februari sampai 9 Maret 2019. Jenis penelitian yang dilakukan adalah penelitian eksperimen dengan pendekatan kuantitatif. Metode penelitian ini menggunakan Quasi Experimental Designs dengan desain Non Equevalent Control Group Design. Populasi sebanyak 29 anak dengan pengambilan sampel menggunakan teknik Total Sampling, sehingga seluruh populasi dijadikan sebagai sampel. Penelitian ini bertujuan untuk mengetahui: (1) Kecerdasan linguistik anak (2) Kecerdasan linguistik anak menggunakan media pop up book (3) Pengaruh yang signifikan media pop up book terhadap kecerdasan linguistik anak di RA Nurhayati Kecamatan Medan Tembung T.A. 2018/2019. Hasil penelitian menunjukkan bahwa penggunaan media pop up book berpengaruh terhadap kecerdasan linguistik anak usia 5-6 tahun. Hal ini tergambar dengan hasil penelitian yang diperoleh rata-rata pre-test 26,72 dan rata-rata post-test 52,08. Sehingga kecerdasan linguistik anak di kelas eksperimen lebih baik dibanding dengan kelas kontrol dengan rata-rata pre-test 25 dan rata-rata post-test 44,83. Berdasarkan hasil uji hipotesis diperoleh thitung > ttabel yaitu 3,226>2,131 dengan angka signifikan sebesar $\alpha=0,05$. Dengan demikian hipotesis Ho ditolak dan Ha diterima sehingga dapat dinyatakan Ada Pengaruh yang Signifikan dari Penggunaan Media Pop Up Book terhadap Kecerdasan Linguistik Anak Usia 5-6 Tahun di RA Nurhayati Kecamatan Medan Tembung T.A. 2018/2019.
\end{abstract}

Kata Kunci : Media Pop Up Book, Kecerdasan Linguistik, Pendidikan Anak Usia Dini

\begin{abstract}
This research was conducted in RA Nurhayati, Medan Tembung District, on February 25 to March 9, 2019. The type of research carried out was an experimental study with a quantitative approach. This research method uses Quasi Experimental Designs with Non Equevalent Control Group Design. The population of 29 children by sampling using the Total Sampling technique, so that the entire population is used as a sample. This study aims to determine: (1) Children's linguistic intelligence (2) Children's linguistic intelligence using pop up book media (3) Significant influence of pop up book media on children's linguistic intelligence in RA Nurhayati District Medan Tembung T.A. 2018/2019. The results showed that the use of pop-up media influenced linguistic intelligence of children aged 5-6 years. This is illustrated by the results of the study obtained an average pre-test 26.72 and an average post-test of 52.08. So that the linguistic intelligence of children in the experimental class is better than the control class with an average pre-test 25 and an average post-test of 44.83. Based on the results of hypothesis testing obtained tcount $>$ ttable is $3.226>2.131$ with a significant number of $\alpha=0.05$. Thus the hypothesis Ho is rejected and Ha is accepted so that it can be stated There is a Significant Effect of the Use of Pop Up Book Media on Linguistic Intelligence of Children Aged 5-6 Years in RA Nurhayati Medan Tembung District T.A. 2018/2019.
\end{abstract}

Keywords : Media Pop Up Book, Linguistic Intelligence, Early Childhood Education

Corespondency Author:

* desimaisura96@gmail.com

**kkhadijah@uinsu.ac.id

*** rohanisitorus@uinsu.ac.id 


\section{A. Pendahuluan}

Howard Gardner sang pencetus dari teori kecerdasan jamak mengawali teorinya dengan percobaan dalam kelas eksperimen telah menemukan bahwa setiap anak mempunyai kecerdasan yang berbeda sehingga merekapun juga memerlukan stimulasi atau teknik pembelajaran yang berbeda sesuai dengan kecerdasan mereka masing-masing. Setiap anak mempunyai kecerdasan yang berbeda dalam menerima dan memahami setiap informasi.

Perkembangan bahasa pertama anak-anak dapat dipandang sebagai suatu pertumbuhan yang berjalan perlahan menuju penguasaan kaidah-kaidah bahasa yang semakin lama semakin sempurna. Anak-anak memperoleh komponen-komponen perkembangan bahasa pertama mereka dalam waktu yang relatif singkat. Ketika anak mulai bersekolah dan mempelajari bahasa secara formal, anak tersebut sudah mengetahui cara berbicara untuk berkomunikasi dengan orang lain. Anak sudah mengetahui dan mengucapakan sejumlah kosa kata. Namun, perkembangan bahasa anak tidak berhenti ketika anak sudah mulai bersekolah atau sudah dewasa. Proses perkembangan bahasa anak tersebut terus menerus berlangsung sepanjang hayat.

Dengan bahasa, anak mencoba untuk mengkomunikasikan gagasan, pikiran, dan perasaan. Karena itu bahasa adalah bidang yang sangat penting dari perkembangan anak berhubungan dengan bideng lainnya. Para pendidik, orang tua, ahli pendidikan perlu memahami pengembangan bahasa anak karena akan menjadi syarat pengembangan faktor pribadi yang lain dalam diri anak.

Kecerdasan verbal-linguistik adalah kemampuan untuk menggunakan bahasa, termasuk bahasa ibu dan bahasa-bahasa asing, untuk mengekspresikan apa yang ada dipikiran dan memahami orang lain. Kecerdasan linguistik disebut juga kecerdasan verbal karena mencakup kemampuan untuk mengekspresikan diri secara lisan dan tulisan, serta kemampuan untuk menguasai bahasa asing.

Seorang anak memiliki kecerdasan bahasa yang tinggi akan mampu menceritakan cerita dan adegan lelucon, menulis lebih baik dan rata-rata anak yang lain yang memiliki usia yang sama, mempunyai memori tantang nama, tempat, tanggal, dan informasi lain lebih baik dari anak pada umumnya, senang terhadap permainan kata-kata, suka mendengar cerita tanpa melihat buku, mengomunikasikan, pikiran, perasaan, dan ide-ide dengan baik, mendengarkan dan merespons bunyi-bunyi, irama, warna, berbagai kata lisan. 
Di samping itu, anak yang memiliki kecerdasan bahasa yang lebih daripada anak lainnya suka mengajukan banyak pertanyaan, suka bicara, memiliki banyak kosakata, suka membaca dan menulis, memahami fungsi bahasa, dapat berbicara tentang keterampilan bahasa. Oleh karena itu, karier yang sesuai dengan orang yang memiliki kecerdasan verbal yang tinggi adalah penyair, wartawan (jurnalis), ilmuwan, novelis, pemain komedi, pengacara, penceramah, pelatih, guru, dan lain-lain. Menurut Yus (2011) Kecerdasan linguistik anak usia 5-6 tahun meliputi kemampuan: 1) Penggunaan kata penghubung, 2) Keterangan objek/subjek, 3) Kata kerja dasar (infinitif), 4) Kata keterangan (adverb), 5) Kalimat yang menunjukkan tingkat perbandingan, 6) Mendengarkan cerita yang panjang, 7) Pertanyaan, 8) Kata kerja bantu, 9) Bercerita, 10) Mulai membaca, dan 11) Menulis.

Mark Renk Jalongo (dalam Asrul \& Syukrial, 2016) menjelaskan bahwa belajar dalam kerangka komunikasi berkenaan dengan keterampilan linguistik. Karena itu, linguistik bermuara kepada bahasa verbal (lisan dan tulisan) dan bahasa yang dipelajari. Pada dasarnya dua maksud komunikasi yang diperoleh anak usia dini, yaitu: paralinguistik (non verbal), dan linguistik (verbal). Paralinguistik adalah komunikasi non verbal yang berhungan dengan bahasa, seperti ekspresi muka, bahasa tubuh/gestur, poster tubuh, dan intonasi bahasa. Komunikasi bahasa verbal memainkan peran signifikan dalam pemahaman bahasa, khususnya ketika ekspresi bahasa verbal yang hanya berkembang. Dalam faktanya kemungkinan memperoleh esensi pesan tanpa kata-kata tertentu dari semuanya sebagaimana ketika menonton, pada mimik gerakan dalam program televisi dengan adanya daya suara yang tidak ada.

Hal ini sejalan dengan pendapat Triharso (2013) dikatakannya bahwa anak-anak yang berbakat dalam bidang linguistik dapat distimulasi dengan mengucapkan, mendengar dan melihat kata-kata. Cara terbaik yang dapat diterapkan adalah melakukan tanya jawab setelah menyelesaikan suatu kegiatan, memperlihatkan gambar-gambar, mendengarkan kaset/rekaman, dan menciptakan kesempatan untuk latihan menulis dan mencoret-coret. Kegiatan bermain bisa dilakukan dengan peralatan sederhana, misalnya dengan menggunakan media pop up book.

Namun, kenyataan di lapangan berdasarkan hasil pengamatan yang dilakukan peneliti pada tanggal 18-20 Oktober 2018 pada anak kelompok B di RA Nurhayati Tahun Ajaran 2018/2019, diketahui bahwa sebagian besar anak belum menunjukkan kecerdasan linguistik. Penyebab belum munculnya kecerdasan linguistik anak terlihat dari 29 anak, terdapat 19 anak yang masih memiliki kesulitan untuk berbicara. Hal ini terlihat pada saat 
guru mengajak bercerita, hanya 10 anak yang mampu menjawab dua pertanyaan dari guru dan mampu mengutarakan pendapatnya dengan jelas dan lancar.

Belum munculnya kecerdasan linguistik anak sesuai dengan tingkat pencapaian perkembangan di RA Nurhayati disebabkan oleh beberapa hal, antara lain pada saat guru mengajak anak bercerita mereka hanya diam, ketika guru bertanya pada anak mereka belum mampu menjawab pertanyaan yang sesuai, anak juga belum mampu menceritakan kembali isi cerita yang telah didengarnya dan pada saat pembelajaran berlangsung guru hanya bercerita saja tanpa menggunakan media. Padahal media dapat dijadikan sebagai wahana penyalur pesan atau informasi dalam pemberian pengalaman belajar dari guru kepada anak.

Media memiliki peran penting dalam pembelajaran anak usia dini, karena perkembangan anak berada pada masa konkrit. Maka diperlukannya media sebagai saluran penyampaian pesan dari guru kepada anak didik agar informasi tersebut dapat diterima dengan baik. Dengan menggunakan media dalam proses pembelajaran dapat membangkitkan dan menstimulasi ranah kognitif, afektif dan psikmotor.

Media Pop Up merupakan salah satu media yang dapat digunakan sebagai saluran penyampaian pesan dari guru kepada anak. Media Pop Up adalah sebuah buku yang memiliki bagian yang dapat bergerak atau memiliki unsur 3 dimensi yang dapat bergerak ketika halamannya dibuka. Oleh karena itu, apabila dirangkaikan antara media pop up book terhadap kecerdasan linguistik anak merupakan salah satu cara komunikasi lisan melalui dialog antara anak dan guru dalam bentuk tanya jawab menggunakan alat bantu komunikasi berupa sebuah buku yang memiliki tampilan gambar dengan unsur 3 dimensi serta dapat bergerak ketika halamannya dibuka yang dapat membangkitkan minat belajar dan mengembangkan kecerdasan linguistik anak.

Dari latar belakang diatas, maka penulis ingin memaparkan dalam artikel ini adalah bagaimana kecerdasan linguistik anak usia 5-6 tahun pada kelas yang menggunakan media pop up book? bagaimana kecerdasan linguistik anak usia 5-6 tahun pada kelas yang menggunakan media visual? apakah terdapat pengaruh penggunaan media pop up book terhadap kecerdasan linguistik anak usia 5-6 Tahun di RA Nurhayati?

\section{B. Kajian Literatur}

\section{Kecerdasan Linguistik}

Menurut Mulyasa (2012) Anak usia dini adalah individu yang sedang mengalami proses pertumbuhan dan perkembangan yang sangat pesat, bahkan dikatakan sebagai 
lompatan perkembangan. Anak usia dini memiliki rentang usia yang sangat berharga dibanding usia-usia selanjutnya karena perkembangan kecerdasan sangat luar biasa. Gardner (dalam Fadhillah 2014) mengemukakan kecerdasan sebagai kemampuan untuk menyelesaikan masalah atau menciptakan sesuatu yang bernilai dalam suatu budaya. Teori Multiple Intiligence menurut Triharso (2013) bahwa kecerdasan tidak hanya berupa kemampuan untuk menyelesaikan tugas-tugas di sekolah yang lebih banyak kaitannya dengan kemampuan verbal logis, melainkan kecerdasan adalah kumpulan kemampuan yang dimiliki seseorang untuk memahami informasi, mengumpulkan fakta, dan menyampaikan pengetahuan yang didapatnya. Maka dapat disimpulkan bahwa kecerdasan adalah sejumlah kemampuan yang dimiliki seseorang, seperti kemampuan menalar, merencanakan, memecahkan masalah, berpikir abstrak, memahami gagasan, menggunakan bahasa, dan belajar.

Firman Allah dalam QS. An -Nahl ayat 78 yang artinya: "Dan Allah mengeluarkan kamu dari perut ibumu dalam keadaan tidak mengetahui sesuatupun, dan dia memberi kamu pendengaran, penglihatan dan hati, agar kamu bersyukur." Dengan demikian, Allah SWT memberitahukan kepada manusia bahwa di dalam dirinya terdapat potensi yang besar, dan manusia dibekali alat indera untuk dimanfaatkan sebaik-baiknya (khususnya untuk mendekatkan diri kepada Allah SWT). Dalam ayat ini terdapat ajakan untuk mengembangkan potensi edukasi yang kita miliki, dengan mengembangkan potensipotensi yang kita miliki maka kita akan lebih bersyukur kepada Allah dengan segala kemurahan-Nya.

Dari pendapat di atas dapat di simpulkan bahwa kecerdasan adalah suatu kemampuan yang membuat seseorang dapat memecahkan masalah yang terjadi baik dalam diri sendiri maupun di dalam lingkungan masyarakat, dapat berpikir abstrak dan bertindak secara terarah.

Kecerdasan linguistik-verbal atau dikenal dengan istilah pintar kata adalah kemampuan untuk menggunakan bahasa baik lisan maupun tulisan secara tepat dan akurat. Menggunakan kata merupakan cara utama untuk berfikir dan menyelesaikan masalah bagi orang yang memiliki kecerdasan ini. Mereka cenderung mempunyai keterampilan reseptif (input) auditori dan produktif (output) verbal yang sangat baik. Mereka menggunakan kata untuk membujuk, mengajak, membantah, menghibur, atau membelajarkan orang lain. Menurut Yaumi dan Ibrahim (2013) bahwa pekerjaan yang sangat disukai oleh mereka yang memiliki kecerdasan linguistik-verbal adalah: guru, pendongeng, pembawa acara, 
wartawan, penulis, pengarang, kepala sekolah, pelawak, pembaca berita di radio atau televisi, editor surat kabar, penyair, dan lain-lain.

Menurut Kurniawan (2016) kecerdasan linguistik merupakan kecerdasan yang mampu mengoptimalkan anak dalam menggunakan kata-kata secara baik dan efektif, baik lisan (misalnya, sebagai seorang orator, pendongeng, atau politisi) maupun tulisan (misalnya, sebagai seorang penyair, penulis, penulis naskah drama, editor dan jurnalis). Kecerdasan ini mencakup kemampuan untuk memanipulasi sintaks atau struktur bahasa, baik kata, lambang bunyi, sistem kalimat, arti, maupun wacana dalam dimensi pragmatisnya. Efendi (2015) berpendapat bahwa kecerdasan linguistik adalah kemampuan akal peserta didik untuk menggunakan kata-kata secara efektif, baik secara lisan maupun dalam bentuk tulisan. Thomas Armstrong (dalam Zulkifli, 2012) menyatakan bahwa kecerdasan linguistik adalah kemampuan menggunakan kata-kata secara efektif.

Berdasarkan pendapat para ahli mengenai pengertian kecerdasan linguistik dapat disimpulkan bahwa kecerdasan linguistik adalah kemampuan seseorang dalam menggunakan atau mengolah gagasan yang akan disampaikan kepada orang lain melalui kata-kata atau bahasa. Jadi kecerdasan linguistik mempengaruhi kemampuan seseorang dalam mengkomunikasikan gagasannya. Anak yang memiliki kecerdasan linguistik yang baik, maka anak tersebut akan mampu berkomunikasi dengan orang lain baik secara lisan maupun non lisan.

Yus (2011) berpendapat bahwa kecerdasan linguistik anak usia 5-6 tahun meliputi kemampuan: 1) Penggunaan kata penghubung, 2) Keterangan objek/subjek, 3) Kata kerja dasar (infinitif), 4) Kata keterangan (adverb), 5) Kalimat yang menunjukkan tingkat perbandingan, 6) Mendengarkan cerita yang panjang, 7) Pertanyaan, 8) Kata kerja bantu, 9) Bercerita, 10) Mulai membaca, dan 11) Menulis. Sedangkan menurut Munafiah (2018) kecerdasan linguistik pada anak usia 5-6 tahun mempunyai beberapa indikator seperti: 1)Menulis lebih baik dari anak seumurannya, 2) Suka berbicara dan menyampaikan cerita yang lucu, 3) Mempunyai memori yang baik untuk nama, tempat, tinggal, atau hal sepele, 4) Senang bermain kata-kata, 5) Senang membaca buku, 6) Mampu mengucapkan katakata sulit secara akurat dibandingkan anak-anak seusianya, 7) Menghargai sajak-sajak walaupun berupa kata-kata yang tidak masuk akal, 8) Suka mendengarkan kata-kata lisan, 9) Memiliki kosa kata yang lebih baik dari anak seusianya, dan 10) Mampu berkomunikasi dengan orang lain melalui cara yang verbal. 
Adapun secara rinci faktor-faktor yang mempengaruhi kecerdasan linguistik anak, yaitu: 1) Faktor kesehatan merupakan faktor yang sangat mempengaruhi perkembangan bahasa anak terutama pada usia awal kehidupannya. Apabila pada usia dua tahun pertama, anak mengalami kelambatan atau kesulitan dalam perkembangan bahasanya. Oleh karena itu, untuk memelihara perkembangan anak secara normal, orang tua perlu memperhatikan kondisi kesehatan anak. Upaya yang dapat ditempuh ialah dengan cara memberikan ASI, makanan yang bergizi, memelihara kebersihan tubuh anak, atau secara reguler memeriksakan anak ke dokter atau puskesmas. 2) Intelegensi, perkembangan bahasa anak dapat dilihat dari perkembangan intelegensinya.Anak yang perkembangan bahasanya cepat, pada umumnya mempunyai intelegansi normal. 3) Status sosial ekonomi keluarga, anak yang berasal dari keluarga kurang mampu mengalami kelambatan dalam perkembangan bahasa dibandingkan dengan anak yang berasal dari keluarga yang mampu.Kondisi ini terjadi mungkin saja disebabkan oleh perbedaan kecerdasan atau kesempatan belajar. 4) Jenis kelamin, pada tahun pertama usia anak tidak ada perbedaan dalam vokalisasi antara pria dan wanita. Namun mulai usia dua tahun, anak wanita menunjukkan perkembangan yang lebih cepat dari anak pria. 5) Hubungan keluarga dimaknai sebagai proses pengalaman berinteraksi dan berkomunikasi dengan lingkungan keluarga, terutamadengan orang tua yang mengajar, melatih, dan memberikan contoh berbahasa kepada anak.

\section{Media Pop Up Book}

Menurut Bluemel \& Taylor (2012) Pop-up Book is a book that offers the potential for motion and interaction through the use of paper mechanisms such as folds, scrolls, slides, tabs, or wheels. These books don't necessarily "pop-up”, but they have motion. There are purists who prefer to reserve the term "pop-up" for those books with motion created by illustrations or figures springing from the page. Sometimes these types of books are also called "movable books" or "interactive books". In this book, we have included books that demonstrate a wide range of mechanisms that lend them motion. Dapat diartikan bahwa Buku Pop-up adalah buku yang menawarkan potensi gerak dan interaksi melalui penggunaan mekanisme kertas seperti lipatan, gulungan, slide, tab, atau roda. Buku-buku ini tidak harus pop-up, tetapi mereka memiliki gerakan.Ada puritan yang lebih suka untuk mencadangkan istilah pop-up untuk buku-buku dengan gerakan yang diciptakan oleh ilustrasi atau angka-angka yang muncul dari halaman. Kadang-kadang jenis buku ini juga disebut buku bergerak atau buku interaktif. 
Johnson (2013) mengemukakan bahwa Pop-up is flat paper form that, by opening a folded sheet to which it is attached, becomes a three-dimensional structure. It then returns to a flat form again when the sheet is closed. The pop-up is either an integral part of a base sheet or an addition to it. It must also be part of, or attached to, both left and right 'page' sides and therefore cross the centre crease. Dapat diartikan bahwa Pop-up adalah bentuk kertas yang datar, dengan membuka lembaran terlipat yang melekat, menjadi struktur tiga dimensi. Kemudian kembali ke bentuk rata lagi ketika lembaran ditutup. Munculan adalah bagian integral dari lembar dasar atau tambahan untuk itu. Itu juga harus menjadi bagian dari, atau melekat pada, kedua sisi 'halaman' kiri dan karena itu melintasi lipatan tengah. Maka dapat disimpulkan bahwa media Pop Up Book adalah tampilan gambar yang memiliki unsur tiga dimensi yang memberikan visualisasi yang unik, menarik dan bermakna, serta dapat bergerak ketika halamannya dibuka, dan dapat menarik perhatian anak dalam proses pembelajaran.

Langkah-langkah penggunaan media pop up book adalah sebagai berikut: 1) Penggunaan media pop up book dapat dilakukan dengan menceritakan sebuah gambar tiga dimensi kepada anak; 2) Terlebih dahulu guru menceritakan didepan kelas, dengan menggunakan ekspresi yang membuat anak tertarik untuk mendengarkan cerita tersebut; 3) Dipertengahan cerita guru dapat menanyakan tentang pengalaman anak sesuai dengan yang diceritakan; 4) Setelah selesai guru dapat menanyakan kembali tentang isi cerita tersebut; 5) Guru tidak hanya sendirian menggunakan media tersebut untuk menjelaskan isi cerita, tetapi peserta didik diberikan kesempatan untuk ikut memanipulasi sehingga terlibat aktif menggunakan media tersebut.

Johnson (2013) mengemukakan kelebihan dari penggunaan media pop-up book adalah: Pop-ups tend to be part of a broader context or have a specific function-illustrating a fictional narrative or the focus of a greeting card, for example. So pop-up workshops with children address the acquisition of paper technology, visual art, and literacy skills. How exciting it is for children to pen a story or 'come up' with an original slogan for a birthday card to accompany their pop-up project!. Pop-up cenderung menjadi bagian dari konteks yang lebih luas atau memiliki fungsi khusus yang menggambarkan narasi fiksi atau fokus kartu ucapan, misalnya jadi lokakarya pop-up dengan anak-anak membahas tentang perolehan teknologi kertas, seni visual, dan keterampilan membaca. Betapa menariknya bagi anak-anak untuk menulis cerita atau 'muncul' dengan slogan asli untuk kartu ulang tahun untuk menemani proyek pop-up mereka!. 
Menurut Bluemel \& Taylor (2012) kelebihan media pop-up book adalah It can be used very effectively to promote a love of story, to motivate reading, and to stimulate interest at hand. Buku pop-up dapat digunakan dengan sangat efektif untuk menyalurkan kecintaan akan cerita, memotivasi membaca, dan untuk merangsang minat.

Kekurangan media pop-up book diantaranya Menurut Indriana, kekurangan media pop up book meliputi: membutuhkan keterampilan khsusus dalam pembuatannya dan penyajian pesannya berupa unsur visual saja. Sedangkan menurut Dzuanda, menyebutkan beberapa kekurangan pop up book adalah: waktu pengerjaannya cenderung lama, menuntut ketelitian, biaya yang dikeluarkan lebih mahal dibandingkan dengan buku pada umumnya. (Safitri, 2015)

\section{Metode Penelitian}

Penelitian ini menggunakan jenis penelitian Quasi Eksperimental. Menurut Sugiyono (2013) Quasi Eksperimental Desain mempunyai kelompok kontrol, tetapi tidak dapat berfungsi sepenuhnya mengontrol variabel-variabel luar yang mempengaruhi pelaksanaan eksperimen. Sehingga pada penelitian ini menggunakan sampel untuk kelompok eksperimen dan sampel kelompok kontrol. Maisarah (2019) berpendapat bahwa populasi adalah seluruh subjek yang memenuhi karakteristik penelitian yang telah ditetapkan dan sampel adalah sebagian dari populasi yang representatif (dapat mewakili jumlah, karakteristik, dan peran populasi). Dengan demikian, sampel pada penelitian ini adalah 15 orang anak kelas Shofa dan 14 orang anak kelas Marwah yang mewakili keseluruhan anak usia dini di RA Nurhayati.

Adapun instrumen yang akan digunakan pada penelitian ini yaitu: lembar observasi dan rubrik penilaian. Lembar observasi berisi daftar perilaku yang mungkin timbul dan akan diamati ketika anak belajar menggunakan media pop up book. Teknik analisis data pada penelitian ini akan menggunakan dua statistik, yaitu uji hipotesis. Menurut Santoso (2014) bahwa dalam melakukan uji hipotesis, ada banyak faktor yang menentukan, seperti apakah sampel yang diambil berjumlah banyak atau hanya sedikit, apakah standar deviasi populasi diketahui, apakah varians populasi diketahui, metode parametik apakah yang dipakai, dan seterusnya. Dikarenakan sampel berdistribusi normal dan bervarians homogen, maka perhitungan menggunakan uji-t dengan rumus yaitu:

$$
t_{\text {hitung }}=\frac{\bar{x}_{1}-\bar{x}_{2}}{S \sqrt{\frac{1}{n_{1}}+\frac{1}{n_{2}}}}
$$




\section{Hasil Temuan dan Pembahasan}

Proses dalam memperoleh hasil data, sebelum memberikan perlakuan, peneliti melakukan sebuah observasi awal terhadap kedua kelas sampel. Kemudian setelah melakukan observasi awal selanjutnya proses yang dilakukan adalah memberikan perlakuan kepada kelas eksperimen dengan jumlah anak 15 orang dan pada kelas kontrol yang tidak diberikan perlakuan dengan jumlah anak 14 orang.

Setelah dilakukan penelitian pada kedua kelas sampel yaitu kelas eksperimen dan kelas kontrol yang memperoleh hasil akhir yang berbeda dengan skor pada kelas eksperimen rata-rata 52,08 dan skor pada kelas kontrol dengan rata-rata 44,83. Dari data yang diperoleh tersebut terdapat perbedaan yang signifikan antara pengaruh media pop up book terhadap kecerdasan linguistik, pada kelas eksperimen yang diberikan perlakuan dengan menggunakan media pop up book sedangkan di kelas kontrol yang tidak diberi perlakuan. Data hasil observasi kecerdasan linguistik anak pada kelas eksperimen (pretest) disajikan pada tabel berikut:

Tabel 1. Kecerdasan Linguistik Anak Pada Kelas Eksperimen (Pre-Test)

\begin{tabular}{|c|c|c|c|c|c|}
\hline \multirow{2}{*}{ No. } & \multirow{2}{*}{ Interval } & \multirow{2}{*}{ Frekuensi } & \multirow{2}{*}{ Presentase } & \multicolumn{2}{|c|}{ Kumulatif } \\
\cline { 5 - 6 } & & & & Frekuensi & Presentase Kumulatif \\
\hline 1. & $20-22$ & 2 & $13,33 \%$ & 2 & $13,33 \%$ \\
\hline 2. & $23-25$ & 4 & $26,67 \%$ & 6 & $40,00 \%$ \\
\hline 3. & $26-28$ & 3 & $20,00 \%$ & 9 & $60,00 \%$ \\
\hline 4. & $29-31$ & 2 & $13,33 \%$ & 11 & $73,33 \%$ \\
\hline 5. & $32-34$ & 4 & $26,67 \%$ & 15 & $100,00 \%$ \\
\hline \multicolumn{2}{|c}{ Jumlah } & $\mathbf{1 5}$ & $\mathbf{1 0 0 \%}$ & $\mathbf{1 5}$ & $\mathbf{1 0 0 \%}$ \\
\hline
\end{tabular}

Berdasarkan tabel di atas, diketahui bahwa peserta didik di kelas eksperimen (pretest) yang memiliki kategori terendah (20-22, 23-25) sebanyak 6 anak, skor kategori menengah (26-28) sebanyak 3 anak dan skor kategori tertinggi (29-31, 32-34) sebanyak 6 anak. Data hasil observasi kecerdasan linguistik anak pada kelas eksperimen (Post-Test) disajikan pada tabel berikut: 
Tabel 2. Kecerdasan Linguistik Anak Pada Kelas Eksperimen (Post-Test)

\begin{tabular}{|c|c|c|c|c|c|}
\hline \multirow{2}{*}{ No. } & \multirow{2}{*}{ Interval } & \multirow{2}{*}{ Frekuensi } & \multirow{2}{*}{ Presentase } & \multicolumn{2}{|c|}{ Kumulatif } \\
\cline { 5 - 6 } & & & & Frekuensi & Presentase Kumulatif \\
\hline 1. & $42-45$ & 1 & $6,67 \%$ & 1 & $6,67 \%$ \\
\hline 2. & $46-49$ & 3 & $20,00 \%$ & 4 & $26,67 \%$ \\
\hline 3. & $50-53$ & 4 & $26,67 \%$ & 8 & $53,33 \%$ \\
\hline 4. & $54-57$ & 5 & $33,33 \%$ & 13 & $86,67 \%$ \\
\hline 5. & $58-61$ & 2 & $13,33 \%$ & 15 & $100,00 \%$ \\
\hline \multicolumn{2}{|c|}{ Jumlah } & $\mathbf{1 5}$ & $\mathbf{1 0 0 \%}$ & $\mathbf{1 5}$ & $\mathbf{1 0 0 \%}$ \\
\hline
\end{tabular}

Berdasarkan tabel di atas, diketahui bahwa peserta didik di kelas eksperimen (posttest) yang memiliki kategori terendah (42-45, 46-49) sebanyak 4 anak, skor kategori menengah (50-53) sebanyak 4 anak dan skor kategori tertinggi (54-57, 58-61) sebanyak 7 anak. Data hasil observasi kecerdasan linguistik anak pada kelas kontrol (Pre-Test) disajikan pada tabel berikut:

Tabel 3. Kecerdasan Linguistik Anak Pada Kelas Kontrol (Pre-Test)

\begin{tabular}{|c|c|c|c|c|c|}
\hline \multirow{2}{*}{ No. } & \multirow{2}{*}{ Interval } & \multirow{2}{*}{ Frekuensi } & \multirow{2}{*}{ Presentase } & \multicolumn{2}{|c|}{ Kumulatif } \\
\cline { 5 - 6 } & & & & Frekuensi & Presentase Kumulatif \\
\hline 1. & $18-20$ & 2 & $14,29 \%$ & 2 & $14,29 \%$ \\
\hline 2. & $21-23$ & 5 & $35,71 \%$ & 7 & $50,00 \%$ \\
\hline 3. & $24-26$ & 2 & $14,29 \%$ & 9 & $64,29 \%$ \\
\hline 4. & $27-29$ & 1 & $7,14 \%$ & 10 & $71,43 \%$ \\
\hline 5. & $30-32$ & 4 & $28,57 \%$ & 14 & $100,00 \%$ \\
\hline \multicolumn{2}{|r}{ Jumlah } & $\mathbf{1 4}$ & $\mathbf{1 0 0 \%}$ & $\mathbf{1 4}$ & $\mathbf{1 0 0 \%}$ \\
\hline
\end{tabular}

Berdasarkan tabel di atas, diketahui bahwa peserta didik di kelas kontrol (pre-test) yang memiliki kategori terendah (18-20, 21-23) sebanyak 7 anak, skor kategori menengah (24-26) sebanyak 2 anak dan skor kategori tertinggi (27-29, 30-32) sebanyak 4 anak. Data hasil observasi kecerdasan linguistik anak pada kelas kontrol (Post-Test) disajikan pada tabel berikut: 
Tabel 4. Kecerdasan Linguistik Anak Pada Kelas Kontrol (Post-Test)

\begin{tabular}{|c|c|c|c|c|c|}
\hline \multirow{2}{*}{ No. } & \multirow{2}{*}{ Interval } & \multirow{2}{*}{ Frekuensi } & \multirow{2}{*}{ Presentase } & \multicolumn{2}{|c|}{ Kumulatif } \\
\cline { 5 - 6 } & & & & Frekuensi & Presentase Kumulatif \\
\hline 1. & $35-38$ & 2 & $14,29 \%$ & 2 & $14,29 \%$ \\
\hline 2. & $39-42$ & 3 & $21,43 \%$ & 5 & $35,71 \%$ \\
\hline 3. & $43-46$ & 3 & $21,43 \%$ & 8 & $57,14 \%$ \\
\hline 4. & $47-50$ & 3 & $21,43 \%$ & 11 & $78,57 \%$ \\
\hline 5. & $51-54$ & 3 & $21,43 \%$ & 14 & $100,00 \%$ \\
\hline \multicolumn{2}{|c|}{ Jumlah } & $\mathbf{1 4}$ & $\mathbf{1 0 0 \%}$ & $\mathbf{1 4}$ & $\mathbf{1 0 0 \%}$ \\
\hline
\end{tabular}

Berdasarkan tabel di atas diketahui bahwa peserta didik di kelas kontrol yang memiliki skor kategori terendah $(35-38,39-42)$ sebanyak 5 anak. Skor kategori menengah (43-46) sebanyak 3 anak dan skor kategori tertinggi (47-50, 51-54) sebanyak 6 anak.

Berdasarkan data hasil observasi kelas eksperimen dan kelas kontrol di atas, maka dijelaskan bahwa anak kelas eksperimen memiliki nilai terendah, nilai menengah, dan nilai rata-rata tertinggi dibandingkan kelas kontrol. Hal ini menunjukkan bahwa kecerdasan linguistik anak dengan menggunakan media pop up book lebih baik dibandingkan dengan anak pada kelas kontrol. Setelah data memenuhi persyaratan Normalitas dan Homogenitas, maka selanjutnya dilakukan pengujian Hipotesis dengan menggunakan statistic uji-t terhadap data yang diperoleh melalui observasi awal dan observasi akhir dari kelas eksperimen dan kelas kontrol. Ringkasan hasil uji-t diperoleh pada tabel berikut:

Tabel 5. Hasil Uji Hipotesis

\begin{tabular}{|c|c|c|c|c|}
\hline Data & Jumlah Anak & $\mathbf{t}_{\text {hitung }}$ & $\mathbf{t}_{\text {tabel }}$ & Kesimpulan \\
\hline $\begin{array}{c}\text { Kecerdasan Linguistik Anak } \\
\text { Melalui Media Pop Up Book }\end{array}$ & 15 & 3,226 & 2,131 & $\begin{array}{c}\text { Ada pengaruh } \\
\text { yang signifikan }\end{array}$ \\
\hline
\end{tabular}

Berdasarkan data tabel di atas observasi nilai akhir kelas eksperimen dan nilai akhir kelas kontrol diperoleh thitung 3,226 dan ttabel 2,131, maka dapat disimpulkan bahwa ada pengaruh yang signifikan dari media pop up book terhadap kecerdasan linguistik anak usia 5-6 Tahun di RA Nurhayati Kecamatan Medan Tembung T.A 2018/2019 dengan angka signifikan $\alpha=0,05$. 
Hasil penelitian ini didukung oleh beberapa hasil penelitian terdahulu dan pendapat ahli, diantaranya yaitu hasil penelitian Kurniawati dan Sartinah (2014) yang membuktikan bahwa metode bercakap-cakap berbasis media pop-up book dapat mempengaruhi kemampuan berbicara anak kelompok A. Triharso (2013) berpendapat bahwa anak-anak yang berbakat dalam bidang linguistik dapat distimulasi dengan mengucapkan, mendengar dan melihat kata-kata. Cara terbaik yang dapat diterapkan adalah melakukan tanya jawab setelah menyelesaikan suatu kegiatan, memperlihatkan gambar-gambar, mendengarkan kaset/rekaman, dan menciptakan kesempatan untuk latihan menulis dan mencoret-coret. Kegiatan bermain bisa dilakukan dengan peralatan sederhana, misalnya dengan menggunakan media pop up book.

Menurut Khadijah (2015) bahwa media memiliki peran penting dalam pembelajaran anak usia dini, karena perkembangan anak berada pada masa konkrit. Maka diperlukannya media sebagai saluran penyampaian pesan dari guru kepada anak didik agar informasi tersebut dapat diterima dengan baik. Dengan menggunakan media dalam proses pembelajaran dapat membangkitkan dan menstimulasi ranah kognitif, afektif dan psikmotor. Hal ini dikarenakan media pop up book merupakan media pengajaran yang unik, kreatif, menarik dan mampu menumbuhkembangkan minat belajar anak sesuai dengan pokok bahasan atau materi yang sedang dijelaskan. Melalui media pop up book anak bisa diajak secara langsung dalam mempraktekkan materi yang telah disajikan didepan kelas dan media pop up book ini memudahkan anak untuk mengingat apa yang sudah dijelaskan oleh guru didepan kelas.

Penggunaan media pop up book ini, selain berpengaruh pada kecerdasan linguistik anak juga berpengaruh pada aspek kognitif, agama, sosial emosional dan seni anak, karena media pop up book ini memiliki suatu gambar tiga dimensi yang ketika menggunakannya anak harus mengingat kembali isi cerita yang telah dijelaskan guru sebelumnya, pada setiap gambarnya memiliki kebermaknaan yang merujuk pada keagamaan atau ciptaan Tuhan, kesabaran anak diuji ketika anak harus bersabar untuk saling bergantian dengan temannya ketika menggunakan media pop up book ini dan kekreatifitasan anak diasah ketika ia harus memperagakan gaya-gaya tokoh dalam cerita tersebut.

Hasil penerapan menggunakan media pop up book pada kelas eksperimen ternyata cukup memuaskan. Diketahui bahwa kecerdasan linguistik pada kelas eksperimen yang diberikan perlakuan dengan menggunakan media pop up book memiliki pengaruh yang signifikan dari pada kelas kontrol yang tidak diberikan perlakuan atau pembelajaran yang terjadwal dari sekolah tersebut. 


\section{E. Kesimpulan dan Saran}

Berdasarkan hasil penelitian yang telah dilakukan maka dapat disimpulkan sebagai berikut: 1) Kecerdasan linguistik anak pada pre test dan post test di kelas eksperimen menggunakan media pop up book mengalami peningkatan, hal ini dilihat dari skor nilai pre test yaitu 73,33\% dan skor nilai post test yaitu 86,67\%. Maka, peningkatan persentase di kelas eksperimen sebesar 13,34\%. 2) Kecerdasan linguistik anak di kelas kontrol dengan menggunakan media visual juga mengalami peningkatan pada pre test dan post test, dengan skor nilai pre test $71,43 \%$ dan skor nilai post test $78,57 \%$. Maka, peningkatan presentase di kelas kontrol sebesar 7,14\%. 3) Pada pre test dan post test masing-masing kelas yaitu kelas eksperimen dan kelas kontrol mengalami peningkatan. Hal ini menunjukkan bahwa kedua media pembelajaran yakni media pop up book dan media visual sama-sama memberikan pengaruh terhadap kecerdasan linguistik anak. Akan tetapi pada kelas eksperimen yakni menggunakan media pop up book, kecerdasan linguistik anak mengalami peningkatan yang lebih besar. Hal ini juga dibuktikan dari hasil presentase pada kelas eksperimen sebesar 13,34\%, sedangkan pada kelas kontrol sebesar 7,14\%. Dan untuk mengetahui adanya pengaruh yang signifikan dari penggunaan media pop up book terhadap kecerdasan linguistik anak melalui perhitungan uji-t bahwa thitung $>$ ttabel yaitu 3,226>2,131. Maka disimpulkan bahwa hipotesis Ho ditolak dan Ha diterima yaitu terdapat pengaruh yang signifikan dari penggunaan media pop up book terhadap kecerdasan linguistik anak usia 5-6 tahun di RA Nurhayati Kecematan Medan Tembung.

\section{Daftar Pustaka}

Asrul., Syukrial, Ahmad. 2016. Strategi Pendidikan Anak Usia Dini. Medan: Perdana Publishing

Bluemel, Nancy Larson., Taylor, Rhonda Harris. 2012. Pop-up Books: A Guide for Teachers and Librarians. America: ABC-CLIO, LLC.

Departemen Agama RI. 2010. Al-Qur'an dan Terjemah. Bandung: Sygma Examedia Arkanleema.

Efendi, Agus. 2015. Revolusi Kecerdasan. Bandung: Alfabeta.

Fadillah. 2014. Pendidikan Anak Usia Dini. Jakarta: Kencana Prenada Media Group.

Johnson, Paul. 2013. New Pop-Up Paper Projects. New York: Routledge.

Khadijah. 2015. Media Pembelajaran Anak Usia Dini. Medan: Perdana Publishing.

Kurniawan, Heru. 2016. Kreatif Mendongeng Untuk Kecerdasan Jamak Anak. Jakarta: Kencana. 
Kurniawati, Novita. Endang Pudjiastuti Sartinah. (2016). Pengaruh Metode Bercakapcakap Berbasis Media Pop Up Book Terhadap Kemampuan Berbicara Anak Kelompok A, Jurnal PAUD Teratai, Volume 05 Nomor 03.

Maisarah. 2019. Metodologi Penelitian Pendidikan Pendekatan Kuantitatif. Medan: Akasha Sakti.

Mulyasa. 2012. Manajemen PAUD. Bandung: Remaja Rosdakarya.

Munafiah, Nida'ul. 2018. Strategi Pembelajaran PAUD Berbasis Multiple Intelligence. Jawa Tengah: Mangku Bumi.

Triharso, Agung. 2013. Permainan Kreatif dan Edukatif untuk Anak Usia Dini. Jakarta: Andi Publisher.

Yaumi, Muhammad., Ibrahim, Nurdin. 2013. Pembelajaran Berbasis Kecerdasan Jamak (Multiple Intelligences). Jakarta: Kencana.

Yus, Anita. 2011. Model Pendidikan Anak Usia Dini, Jakarta: Kencana.

Zulkifli. 2012. Psikologi Perkembangan. Bandung: Remaja Rosdakarya. 